\title{
SEED METERING MECHANISMS AND TRACTOR-SEEDER FORWARD SPEED ON CORN AGRONOMIC COMPONENTS
}

\author{
Jorge W. Cortez ${ }^{*}$, Matheus Anghinoni ${ }^{1}$, Sálvio N. S. Arcoverde ${ }^{1}$
}

$1^{1 *}$ Corresponding author. Universidade Federal da Grande Dourados/ Dourados - MS, Brasil.

E-mail: jorgecortez@ufgd.edu.br | ORCID ID: http://orcid.org/0000-0003-1120-719X

KEYWORDS
grain yield,
pneumatic sowing,
sowing forward
speed.

\begin{abstract}
Seed metering system and tractor-seeder forward speed are factors that affect sowing. Therefore, this study aimed to evaluate sowing and agronomic components of corn as a function of seed metering mechanism and tractor-seeder forward speed, in addition to evaluating the yield data obtained from a harvester with a yield monitor. The soil of the area is classified as Distroferric Red Latosol. The experiment was set up in the second crop season of 2018 and treatments consisted of two seed metering mechanisms (M) (pneumatic and mechanical), and tractor-seeder forward speeds (S) $\left(3,5,7\right.$, and $\left.9 \mathrm{~km} \mathrm{~h}^{-1}\right)$. The pneumatic system promoted the best longitudinal distribution, with values above $90 \%$, and the increased sowing forward speed reduced normal spacings and increased failure. The interaction $\mathrm{M} \times \mathrm{S}$ indicated that pneumatic seeder promotes the best stand at the highest forward speed, normal spacing, and less failure. The yield data showed less variation with increasing forward speed, and the best result was observed for the mechanical seeder at $5 \mathrm{~km} \mathrm{~h}^{-1}$ when these data are grouped into yield classes.
\end{abstract}

\section{INTRODUCTION}

Second crop corn has great importance to Brazilian agribusiness, which is the third-largest corn producer in the world, with an area of 17.25 million hectares sown and production of 98.5 million tons (CONAB, 2019). In this sense, the second crop corn has gained high prominence, as it has an area of 12 million hectares sown and more than 68 million tons produced in the crop season of 2017 (IBGE, 2018).

Crop rotation has been an ally, but field management is still the succession of soybean in the first crop season and corn in the second crop season. One of the main factors affecting corn yield is the climate, as the later the sowing is carried out, the lower the productive potential and the higher the risk of losses caused by frosts and/or droughts mainly due to the reduced soil water availability and air temperature in the winter. For this reason, the planning of the second crop corn begins in the first crop season, with the choice of soybean cultivars with early cycle for the area release and also a quick crop implementation.
Because such factors are often not properly considered for corn crop implementation, there is a significant reduction in its average yield in Brazilian agriculture for both first and second crop corn (Arcoverde et al., 2017). In addition to corn yield being sensitive to weather events during sowing, which varies in time and space, there is also a strong dependence on seed distribution by the seeder (Vian et al., 2016).

In this context, corn sowing is an essential operation for its establishment in the field, as it is associated with uniformity of longitudinal distribution of seedlings and final stand (Weirich Neto et al., 2015; Arcoverde et al., 2016; Arcoverde et al., 2017). Alonço et al. (2015) verified that sowing is one of the most important management practices associated with crop yield, being essential that this operation be carried out with the highest degree of quality and precision possible.

Among the factors for a fast crop implantation is the tractor-seeder forward speed, which is directly related to the ability of the seeder to work in the field. However, the use of seeders at high forward speeds may impair soil-seed contact (Nascimento et al., 2014), compromising

\footnotetext{
${ }^{1}$ Universidade Federal da Grande Dourados/ Dourados - MS, Brasil.
} 
germination, seed emergence and, consequently, stand (Santos et al., 2016).

The use of seeders with a precision metering device that places seeds at a pre-established sowing density for the crop (Dias et al., 2014) may be an alternative to improve crop yield. Bottega et al. (2018) evaluated the performance of seeders equipped with perforated horizontal disc and pneumatic system at three forward speeds $(4,6$, and $8 \mathrm{~km} \mathrm{~h}^{-1}$ ) in corn crop in a Distroferric Red Latosol under no-tillage system. They found that the use of the pneumatic metering mechanism resulted in better stand formation, reducing failed and double spacings, while the increase in the forward speed caused failures in the longitudinal seed distribution, increasing the occurrence of failed and double spacings. Alonço et al. (2015) found differences in the longitudinal distribution of cotton and sunflower seeds as a function of the type of pneumatic metering mechanism, as well as a reduction of normal spacing and increase of failure with increasing forward speeds $\left(5,7.5\right.$, and $\left.10 \mathrm{~km} \mathrm{~h}^{-1}\right)$, emphasizing that no pneumatic metering presented uniformity of acceptable spacing of $90 \%$.

Considering that corn crop is highly dependent on plant stand to achieve high grain yield since this plant has low recovery capacity (Vian et al., 2016), it is essential to study the operational factors involved in the quality of sowing and implantation of this crop, aiming at the proper longitudinal seed distribution and the correct depth of deposition in the soil because the excellence in the operational process of mechanized sowing contributes to the success of the productive system (Macedo et al., 2016).

Therefore, this study aimed to evaluate sowing quality and agronomic components of corn as a function of pneumatic and mechanical seed metering systems and tractor-seeder forward speed $\left(3,5,7\right.$, and $\left.9 \mathrm{~km} \mathrm{~h}^{-1}\right)$, in addition to analyzing the yield data of treatments obtained through a harvester with embedded technology.

\section{MATERIAL AND METHODS}

This study was carried out at Fazenda São Francisco, located in Rondonópolis, MT, Brazil. The site is located at a latitude of $16^{\circ} 53^{\prime} 41.57^{\prime \prime} \mathrm{S}$ and longitude of $54^{\circ} 48^{\prime} 01.37^{\prime \prime}$ $\mathrm{W}$, with an altitude of $488 \mathrm{~m}$. According to Köppen, the regional climate is classified as Aw. The soil of the area is classified as very clayey Distroferric Red Latosol. Table 1 shows the particle size and chemical analysis of the soil.

TABLE 1. Particle size and soil chemical analysis of the experimental area.

\begin{tabular}{|c|c|c|c|c|c|c|c|c|c|c|c|c|}
\hline \multirow{2}{*}{$\begin{array}{l}\text { Layer } \\
(\mathrm{m})\end{array}$} & $\mathrm{pH}$ & $\mathrm{OM}$ & $\mathrm{P}$ & $\mathrm{K}$ & $\mathrm{Mg}$ & $\mathrm{Ca}$ & $\mathrm{H}+\mathrm{Al}$ & CEC & $\mathrm{V}$ & Clay & Silt & Sand \\
\hline & $\mathrm{Cacl}_{2}$ & $\mathrm{~g} \mathrm{~kg}^{-3}$ & \multicolumn{2}{|c|}{$\mathrm{mg} \mathrm{dm}^{-3}$} & \multicolumn{3}{|c|}{$\mathrm{cmol}_{\mathrm{c}} \mathrm{dm}^{-3}$} & \multicolumn{5}{|c|}{-------------------------- \% } \\
\hline $0.00-0.10$ & 5 & 42.3 & 20.2 & 40 & 0.9 & 2.2 & 4.9 & 8.9 & 44.9 & \multirow{2}{*}{65} & \multirow{2}{*}{7.5} & \multirow{2}{*}{27.5} \\
\hline $0.10-0.20$ & 4.9 & 28.4 & 6.5 & 38 & 0.8 & 3 & 5.1 & 8.3 & 38.6 & & & \\
\hline
\end{tabular}

pH: hydrogen potential (acidity); OM: organic matter; P: phosphorus; K: potassium; Mg: magnesium; Ca: calcium; $\mathrm{H}+\mathrm{Al}$ : hydrogen + aluminum (potential acidity); CEC: cation exchange capacity; V: base saturation.

The experimental area has been used for over 30 years for agriculture, with a no-tillage system in the last ten years. In 2015, Crotalaria spectabilis was sown for green manure, followed by soybean in the first crop season and corn in the second crop season.
The data of precipitation during the experimental period were collected in the field where the experiment was set up. The data of temperature are resulting from the weather station of the Fundação Matogrosso - Cachoeirinha (Figure 1).

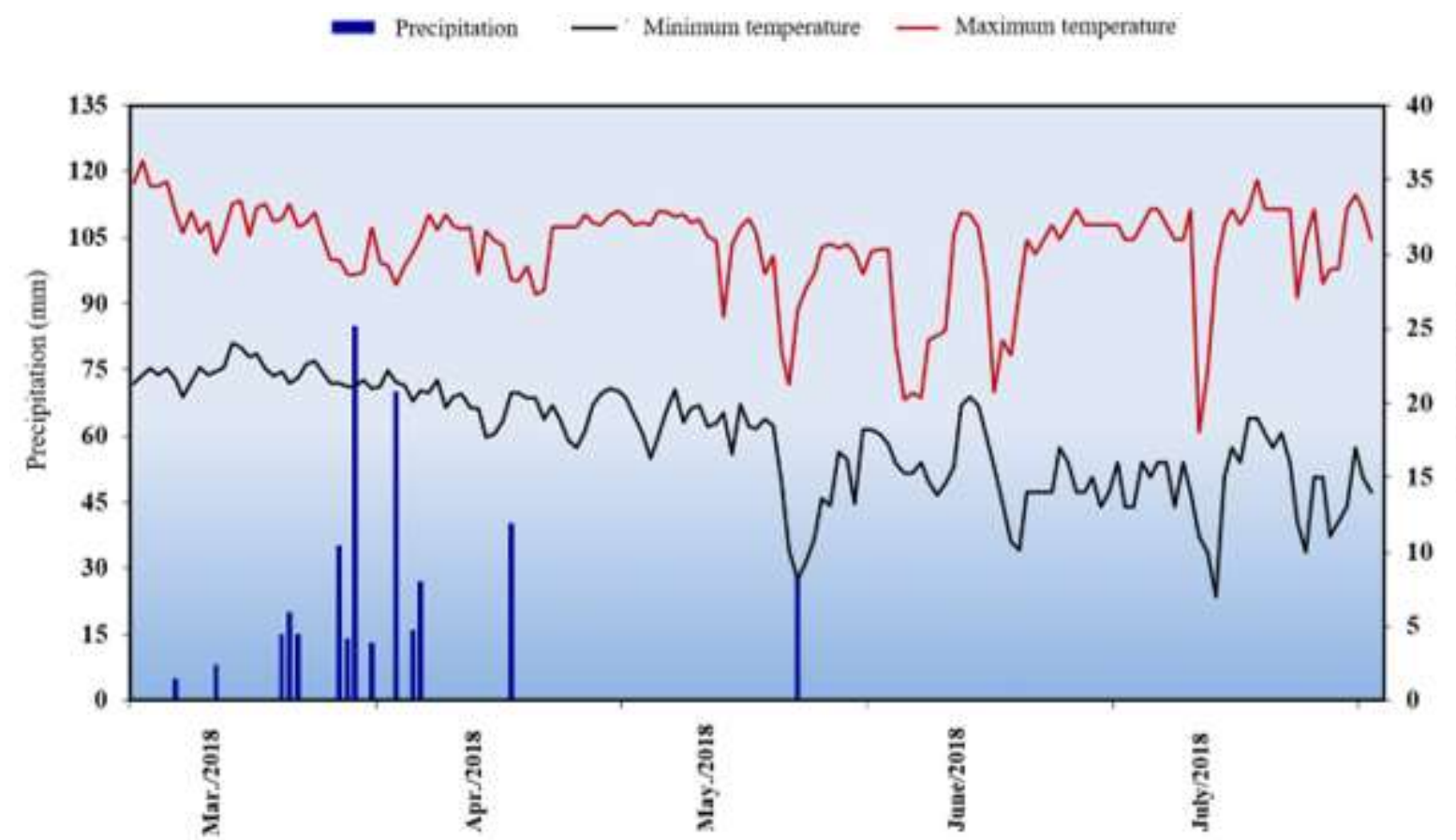

FIGURE 1. Monthly weather data obtained from São Francisco Farm and Cachoeirinha station (FMT) in 2018. 
The experiment was based on a randomized block design in a factorial arrangement, with five replications (blocks) and treatments consisting of two seed metering mechanisms (pneumatic and mechanical and four tractorseeder forward speeds applied at sowing time, obtained by shifting the tractor, resulting in average speeds of 3, 5, 7, and $9 \mathrm{~km} \mathrm{~h}^{-1}$ (S1, S2, S3, and S4, respectively).

Experimental plots had the area as a function of the

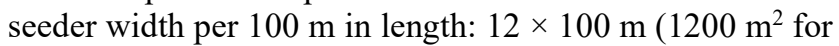
pneumatic mechanism) and $9 \times 100 \mathrm{~m}\left(900 \mathrm{~m}^{2}\right.$ for mechanical mechanism).

Corn hybrid was KWS RB9006, with PRO3 technology, which was sowed on March 1, 2018 (within the recommended period), shortly after soybean harvesting, with the harvest carried out on August 8, 2018, with moisture content close to $14 \%$. Plant density was based on sowing time and region, reaching 60,000 seeds ha ${ }^{-1}$, with an interrow spacing of $0.50 \mathrm{~m}$ and 3 seeds per meter. Monoammonium phosphate (MAP) was distributed in the row at a dose of $100 \mathrm{~kg} \mathrm{ha}^{-1}$, performed by a mismatched double disc during sowing. After crop establishment, $220 \mathrm{~kg} \mathrm{ha}^{-1}$ of the formulation 20-00-20 was applied in two applications of $110 \mathrm{~kg} \mathrm{ha}^{-1}$, one of them immediately after germination and another at the V4 stage. The use of herbicide and insecticide inputs was carried out after previous evaluation of the area and consisted of glyphosate + atrazine and methomyl + novaluron. The use of fungicides was programmed in two applications of azoxystrobin + tebuconazole.

Seeders were from the same manufacturer, but with different seed metering mechanism. Seeder mechanisms had a corrugated cutting disc of $50.8 \mathrm{~cm}$ (20 inches), double disc for fertilizer and seed distribution of 40.6 (16 inches) and $38.1 \mathrm{~cm}$ (15 inches), respectively, double angled wheels (V) for compaction, and pantographic system. The seeder with pneumatic metering device had 24 rows with 30-hole discs, while the seeder with mechanical metering device had 18 rows with 28 -hole discs. The other equipment used to conduct the crop season was a $228 \mathrm{~kW}$ (311 hp) tractor, dual-wheeled front-wheel drive (FWD), and AFS700 autopilot to pull both seeders. A $136 \mathrm{~kW}(185 \mathrm{hp})$ selfpropelled sprayer, with a $27-\mathrm{m}$ boom and 3000 -L tank was also used. The used harvester had $289 \mathrm{~kW}$ (389 hp), axial track system, 11100-L bulk tank, Intelliview IV yield monitor, and 18-row platform.

Plant stand was evaluated with a tape measure in three rows with two meters in length and then the number of plants immediately after crop establishment was counted. The results were obtained in plants per meter and expressed in plants per hectare.

The evaluation of longitudinal distribution or uniformity of spacing between plants was carried out with a measuring tape, and the readings were performed in three rows of each plot in two meters in length. The percentage of normal, failed, and double spacings were obtained according to standards cited by Kurachi et al. (1989), as follows: double spacing (D) $-<0.5$ times reference spacing (Xref), normal spacing (A) $-0.5<$ Xref $<1.5$, failed spacing (F) $->1.5$ Xref. The average reference spacing was $0.33 \mathrm{~m}$.
The other spacings are shown in Table 2.

TABLE 2. Table of interval values for distribution.

\begin{tabular}{lc}
\hline Distribution & Interval $(\mathrm{m})$ \\
\hline Double & $<0.16$ \\
Normal & $0.16-0.50$ \\
Failed & $>0.50$ \\
\hline
\end{tabular}

Stem diameter was measured using a caliper in the projection of the plant neck, approximately $5 \mathrm{~cm}$ from the soil. The determination was performed in 10 plants per plot.

Plant height and first ear insertion height were determined by measuring five plants in the center of the plot in two successive rows. For plant height, the distance from soil level to flag leaf insertion was measured; the first ear insertion height (FEIH) was determined by the distance between soil level and productive FEIH.

The area of each treatment was harvested with a harvester with the system for acquisition of yield data for the application of precision agriculture techniques. It consists of a harvester with impact type yield sensor placed in the bulk tank, with moisture measurement carried out by a sensor placed on the side of the riser pipe in the clean grain elevator.

The data of stand, longitudinal plant distribution, stem diameter, plant height, FEIH, and yield (manual) were submitted to analysis of variance and, when significant, the Tukey test was applied at 5\% probability for comparison of means of agronomic components and distribution, which were then subjected to correlation analysis.

Yield data obtained by the grain harvester were initially subjected to data filtering to eliminate positioning errors, unlikely high and low yields, incorrect platform width, grain moisture, distance between points, filling range, and statistical limits for outliers. Subsequently, the descriptive statistics was carried out, and maps were generated by interpolation by the inverse distance. Yield data obtained from the harvester were also grouped, as defined by Molin (2002), who divides yield percentages into three classes: below $95 \%, 95$ to $105 \%$, and above $105 \%$ of the overall average yield to identify which of the treatments grouped the highest number of points in each class.

\section{RESULTS AND DISCUSSION}

Plant stand showed a significant difference for the metering mechanism (M), but it did not occur for sowing forward speed $(\mathrm{S})$ and the interaction $\mathrm{M} \times \mathrm{S}$ (Table 3 ).

The pneumatic mechanism in seeders favors the highest number of plants per meter, which is related to the lower numerical value of failure plants in the pneumatic metering mechanism. According to Bottega et al. (2018), it can happen through the seed selection and individualization system, which has fewer mechanical components, by the negative pressure. This pneumatic metering system leads to less damage to seeds when compared to the mechanical system with horizontal discs. 
TABLE 3. Plant stand and longitudinal distribution.

\begin{tabular}{|c|c|c|c|c|c|}
\hline \multirow{2}{*}{ Factor } & \multicolumn{2}{|c|}{ Plant stand } & \multicolumn{3}{|c|}{ Longitudinal distribution of plants } \\
\hline & Plants per meter & Plants per hectare & Normal (\%) & Failed $(\%)$ & Double $(\%)$ \\
\hline \multicolumn{6}{|l|}{ Metering $(\mathrm{M})$} \\
\hline Pneumatic & $2.84 \mathrm{a}$ & $57,000 \mathrm{a}$ & $91.88 \mathrm{a}$ & 6.88 & 1.22 \\
\hline Mechanical & $2.69 \mathrm{~b}$ & $54,000 \mathrm{~b}$ & $85.52 \mathrm{~b}$ & 11.63 & 2.83 \\
\hline \multicolumn{6}{|l|}{ Speed (S) } \\
\hline $3.0 \mathrm{~km} \mathrm{~h}^{-1}$ & 2.85 & 57,000 & $94.16 \mathrm{a}$ & $4.50 \mathrm{~b}$ & 1.33 \\
\hline $5.0 \mathrm{~km} \mathrm{~h}^{-1}$ & 2.81 & 56,333 & $94.22 \mathrm{a}$ & $4.66 \mathrm{~b}$ & 1.11 \\
\hline $7.0 \mathrm{~km} \mathrm{~h}^{-1}$ & 2.73 & 54,666 & $86.66 \mathrm{ab}$ & $9.55 \mathrm{ab}$ & 3.77 \\
\hline $9.0 \mathrm{~km} \mathrm{~h}^{-1}$ & 2.70 & 54,000 & $79.77 \mathrm{~b}$ & $18.33 \mathrm{a}$ & 1.88 \\
\hline \multicolumn{6}{|l|}{ F-test } \\
\hline M & $4.31^{*}$ & $4.34^{*}$ & $5.92^{*}$ & $2.79^{\text {ns }}$ & $2.63^{\text {ns }}$ \\
\hline S & $0.96^{\mathrm{ns}}$ & $0.95^{\text {ns }}$ & $7.03^{* *}$ & $5.20^{* *}$ & $1.49^{\text {ns }}$ \\
\hline $\mathrm{M} \times \mathrm{S}$ & $1.47^{\mathrm{ns}}$ & $1.45^{\mathrm{ns}}$ & $2.85^{\mathrm{ns}}$ & $2.18^{\mathrm{ns}}$ & $1.35^{\mathrm{ns}}$ \\
\hline $\mathrm{CV}(\%)$ & 8.18 & 8.20 & 9.31 & 97.11 & 154.86 \\
\hline
\end{tabular}

ns: not significant $(p>0.05) ;{ }^{*}$ : significant $(p<0.05) ;{ }^{* *}$ : significant $(p<0.01) ; C V$ : coefficient of variation. Means followed by different lowercase letters in the column differ from each other by the Tukey test at 5\% probability. P: pneumatic mechanism; M: mechanical mechanism.

The longitudinal distribution of plants (Table 3) showed a significant difference for the normal distribution, taking into account both the metering mechanisms and sowing forward speeds, while failed spacing presented effect only for sowing forward speed, with no difference between treatments for double spacing. Among metering mechanisms, the pneumatic had better results $(>90 \%)$ according to Mialhe (1996) due to its characteristics of not having to fill the alveolus at the moment of seed individualization. The mechanical metering mechanism presented satisfactory value $(>60 \%)$ according to Mialhe (1996), which is the minimum required for quality mechanical sowing. Also, the mechanical mechanism was only $6.36 \%$ less than the pneumatic, requiring only $60 \%$ of regularity.

Increasing sowing forward speed provided less normal spacing and more failed spacing (Table 3). Slower sowing forward speeds favored higher regularity. These data corroborate with Bottega et al. (2018), who reported that the seed metering with alveolar horizontal disc presented a higher average of failed plants when sowing corn. The same was observed for the highest sowing forward speed $\left(8 \mathrm{~km} \mathrm{~h}^{-1}\right)$, as the interaction between metering mechanisms and sowing forward speeds did not show significant differences (Table 3). Increasing sowing forward speed requires more of the metering mechanisms, which can lead to filling error, failure, or lack of seed in mechanism wells and hence lower normal distribution and higher failure.

Sowing forward speeds from 3 to $7 \mathrm{~km} \mathrm{~h}^{-1}$ (Table 3) presented acceptable values of normal spacing, close to $90 \%$. However, a reduction in the number of normal spacings was observed when working above this limit, which agrees with Bottega et al. (2018), who used pneumatic seed metering in corn sowing and observed that the most appropriate plant distribution was performed at speeds of 4 and $6 \mathrm{~km} \mathrm{~h}^{-1}$. Similarly, Alonço et al. (2015) evaluated different pneumatic metering mechanisms and sowing forward speeds $\left(5.0,7.5\right.$, and $\left.10 \mathrm{~km} \mathrm{~h}^{-1}\right)$ and found that an increase in speed significantly influenced the acceptable spacing index, going from 80.47 to $70.53 \%$, on average, which is the same effect found for failed spacings, with means of $5.12,7.47$, and $11.24 \%$ for the mentioned speeds. On the other hand, Bottega et al. (2014a) found a significant reduction in normal spacing at the sowing forward speed of $9.5 \mathrm{~km} \mathrm{~h}^{-1}$ when compared to $4.0 \mathrm{~km} \mathrm{~h}^{-1}$, but not differing from $7 \mathrm{~km} \mathrm{~h}^{-1}$, regardless of the metering, which is similar to that observed by Bottega et al. (2014b) when working with corn sowing at forward speeds of 3.0, 6.0 , and $9.0 \mathrm{~km} \mathrm{~h}^{-1}$.

Coefficient of variation can be classified as low when it is lower than $10 \%$, medium when the $\mathrm{CV}$ is between 10 to $20 \%$, high when it is between 20 to $30 \%$, and very high when CV is above 30\% (Pimentel-Gomes \& Garcia, 2002). The coefficients of variation were low for stand and longitudinal distribution, and very high for failed and double spacings, i.e., the data dispersion is very high because these values are expressed in percentages, not following a pattern, with a random presence. According to Bottega et al. (2014a), a high CV for double spacing can be explained because some treatments had the number of spacings equal to zero, resulting in extreme values, such as 0 and 1 , which is the reason why a high $\mathrm{CV}$ was obtained.

First ear insertion height, stem diameter, plant height, and yield (Table 4) were not influenced by treatments, as well as the interaction between factors. 
TABLE 4. First ear insertion height (FEIH), stem diameter, and plant height.

\begin{tabular}{|c|c|c|c|}
\hline Treatment & $\begin{array}{l}\text { FEIH } \\
(\mathrm{cm})\end{array}$ & Stem diameter $(\mathrm{mm})$ & Plant height $(\mathrm{cm})$ \\
\hline \multicolumn{4}{|l|}{ Metering (M) } \\
\hline Pneumatic & 120.04 & 18.4 & 228.68 \\
\hline Mechanical & 119.44 & 19.8 & 231.64 \\
\hline \multicolumn{4}{|l|}{ Speed (S) } \\
\hline $3.0 \mathrm{~km} \mathrm{~h}^{-1}$ & 120.04 & 19.2 & 227.64 \\
\hline $5.0 \mathrm{~km} \mathrm{~h}^{-1}$ & 120.20 & 20.3 & 233.40 \\
\hline $7.0 \mathrm{~km} \mathrm{~h}^{-1}$ & 118.16 & 19.3 & 229.32 \\
\hline $9.0 \mathrm{~km} \mathrm{~h}^{-1}$ & 120.56 & 17.6 & 230.28 \\
\hline \multicolumn{4}{|l|}{ F-test } \\
\hline $\mathrm{M}$ & $0.11^{\mathrm{ns}}$ & $3.09^{\mathrm{ns}}$ & $1.68^{\mathrm{ns}}$ \\
\hline $\mathrm{S}$ & $0.34^{\mathrm{ns}}$ & $2.06^{\mathrm{ns}}$ & $1.12^{\mathrm{ns}}$ \\
\hline $\mathrm{M} \times \mathrm{S}$ & $0.74^{\mathrm{ns}}$ & $0.50^{\mathrm{ns}}$ & $0.65^{\mathrm{ns}}$ \\
\hline $\mathrm{CV}(\%)$ & 4.84 & 12.79 & 3.13 \\
\hline
\end{tabular}

ns: not significant $(\mathrm{p}>0.05) ;{ }^{*}$ : significant $(\mathrm{p}<0.05) ;{ }^{* *}$ : significant $(\mathrm{p}<0.01)$; CV: coefficient of variation. P: pneumatic mechanism; M: mechanical mechanism.

The fact that there is no effect of treatments for FEIH, diameter, and height can be attributed to the genetic characteristics of the hybrid, indicating the little effect of management on these variables. Although there was a difference in the final plant stand, the largest stand is below recommended.

The data of correlation analysis indicated a relationship between stand and failed and normal distributions, being negative for the former and positive for the latter (Table 5). The higher the stand, the lower the failed spacing in the area, with more normal spacings, indicating better distribution and a stand closer to that set in the seeder. A negative correlation was also observed between normal and failed spacings. Thus, the increased number of normal spacings decreases the failed spacing, which is related to the amount of distributed seeds.

TABLE 5. Correlation analysis between the analyzed variables.

\begin{tabular}{|c|c|c|c|c|c|c|c|}
\hline & Stand & Failed & Double & Normal & Diameter & FEIH & Height \\
\hline Failed & $-0.637 * *$ & & & & & & \\
\hline Double & $0.084^{\mathrm{ns}}$ & $-0.032^{\mathrm{ns}}$ & & & & & \\
\hline Normal & $0.577 * *$ & $-0.939 * *$ & $-0.311^{\mathrm{ns}}$ & & & & \\
\hline Diameter & $-0.110^{\mathrm{ns}}$ & $-0.128^{\mathrm{ns}}$ & $0.2726^{\mathrm{ns}}$ & $0.0286^{\mathrm{ns}}$ & & & \\
\hline FEIH & $-0.028^{\mathrm{ns}}$ & $-0.167^{\mathrm{ns}}$ & $0.0317^{\mathrm{ns}}$ & $0.1483^{\mathrm{ns}}$ & $0.0592^{\mathrm{ns}}$ & & \\
\hline Height & $-0.009^{\mathrm{ns}}$ & $-0.132^{\mathrm{ns}}$ & $0.0404^{\mathrm{ns}}$ & $0.1119^{\mathrm{ns}}$ & $0.2294^{\mathrm{ns}}$ & $-0.041^{\text {ns }}$ & \\
\hline Yield & $-0.095^{\mathrm{ns}}$ & $-0.149^{\mathrm{ns}}$ & $-0.100^{\mathrm{ns}}$ & $0.1766^{\mathrm{ns}}$ & $-0.110^{\mathrm{ns}}$ & $0.1392^{\text {ns }}$ & $-0.049 \mathrm{~ns}$ \\
\hline
\end{tabular}

ns: not significant $(\mathrm{p}>0.05) ;{ }^{*}$ : significant $(\mathrm{p}<0.05) ;{ }^{* *}$ : significant $(\mathrm{p}<0.01)$.

The other variables did not show a correlation with each other. The increased stand, decreasing the number of failed plants and increasing the number of normal spacings, is explained by Bottega et al. (2018), who reported damage to seeds by metering mechanisms. Also, according to Bottega et al. (2014a), the use of higher forward speeds may compromise sowing quality because an increased forward speed leads to a proportional increase in the rotation speed of metering discs, reducing the time available to fill the holes with seeds. Carpes et al. (2018) mentioned that the scraper mechanism might also interfere, as its function may not be properly performed and normal seeds may be excluded (individual), which may cause failure to fill disc holes.

The area sowed with mechanical seeder at $3,5,7$, and $9 \mathrm{~km} \mathrm{~h}^{-1}$ presented yield data of $353,318,346$, and 337, respectively. Zero and extremely high yield values were removed and the other data were filtered based on the standard deviation plus or minus three times, being observed the standard deviation (SD) of the initial value (Table 6) to perform the removal of points, resulting in
$345,310,335$, and 326 yield data for 3.0, 5.0, 7.0, and 9 $\mathrm{km} \mathrm{h}^{-1}$, respectively.

The area sowed with pneumatic seeder at 3, 5, 7, and $9 \mathrm{~km} \mathrm{~h}^{-1}$ showed yield data of $943,775,618$, and 618 , respectively. The same procedures were adopted for the pneumatic seeder, resulting in 928, 761, 603, and 603 yield data for $3,5,7$, and $9 \mathrm{~km} \mathrm{~h}^{-1}$, respectively.

The average yield obtained by the harvest monitor (Table 6) at a sowing forward speed of $3 \mathrm{~km} \mathrm{~h}^{-1}$ showed little difference when comparing both metering mechanisms. The mechanical metering mechanism presented higher numerical yield values at a forward speed of 5 and $7 \mathrm{~km} \mathrm{~h}^{-1}$, but the pneumatic metering mechanism presented higher value at the highest sowing forward speed $\left(9 \mathrm{~km} \mathrm{~h}^{-1}\right)$, reinforcing the speeds proposed by Cortez et al. (2006), for whom mechanical and pneumatic metering devices should present maximum speeds of 8 and up to 11 $\mathrm{km} \mathrm{h}^{-1}$, respectively. Moisture remained constant, close to that of $15 \%$ determined on the monitor. 
TABLE 6. Yield data obtained from harvester $\left(\mathrm{kg} \mathrm{ha}^{-1}\right)$ and grain moisture.

\begin{tabular}{cccccccc}
\hline Seeder & $\begin{array}{c}\text { Speed } \\
\mathrm{km} \mathrm{h}^{-1}\end{array}$ & $\%$ & Moisture & \multicolumn{3}{c}{ Grain yield $\left(\mathrm{kg} \mathrm{ha}^{-1}\right)$} \\
& & & & SD & CV & Min & Max \\
\hline Mechanical & 3 & 14.98 & 6637.55 & 769.11 & 11.58 & 1472.55 & 13621.79 \\
& 5 & 15.09 & 6680.11 & 1950.29 & 23.14 & 1679.59 & 18518.51 \\
& 7 & 15.13 & 6839.90 & 418.66 & 6.12 & 4253.47 & 9343.43 \\
& 9 & 15.08 & 6431.05 & 585.32 & 9.10 & 1766.94 & 14021.16 \\
\hline Pneumatic & 3 & 15.73 & 6660.16 & 1183.60 & 17.77 & 519.23 & 11111.11 \\
& 5 & 15.52 & 6140.33 & 823.16 & 13.41 & 2482.27 & 9259.26 \\
& 7 & 15.28 & 6368.38 & 720.86 & 11.32 & 918.12 & 9259.26 \\
& 9 & 15.04 & 6628.48 & 651.64 & 9.83 & 2256.94 & 9523.81 \\
\hline Mechanical & 3 & 14.97 & 6678.56 & 430.01 & 6.43 & 5135.39 & 8153.48 \\
& 5 & 15.09 & 6539.51 & 908.05 & 13.89 & 2111.11 & 10185.19 \\
& 7 & 15.11 & 6945.60 & 404.10 & 5.82 & 5777.78 & 8088.89 \\
& 9 & 15.07 & 6573.50 & 435.10 & 6.62 & 5086.07 & 8088.24 \\
\hline Pneumatic & 3 & 15.83 & 6697.29 & 1069.86 & 15.97 & 3111.11 & 10185.19 \\
& 5 & 15.51 & 6149.97 & 761.32 & 12.38 & 3858.02 & 8457.71 \\
& 7 & 15.28 & 6406.33 & 553.22 & 8.64 & 4222.22 & 8333.33 \\
& 9 & 15.03 & 6660.36 & 520.03 & 7.81 & 4678.36 & 8457.71 \\
\hline
\end{tabular}

SD: standard deviation; CV: coefficient of variation; Min: minimum; Max: maximum.

According to Molin (2002), the CV data for yield must be below $30 \%$ to be classified with consistency. Thus, the data obtained through the harvest monitor are consistent, with the lowest value $(6.12 \%)$ for the mechanical system at a forward speed of $7 \mathrm{~km}^{-1}$ and the highest value $(23.14 \%)$ for the same metering unit, but at a forward speed of $5 \mathrm{~km} \mathrm{~h}^{-1}$, thus showing that the pneumatic metering system had less variation between the yield values, with a difference of $3.58 \%$, while the mechanical system had a difference of $17.02 \%$. After filtering the data, the coefficients of variation became even lower, improving the consistency of the data obtained in the field (Table 6). The mechanical seeder at a speed of 5 $\mathrm{km} \mathrm{h}^{-1}$ (Table 7) showed the largest amount of area in the class above $105 \%$, according to the yield classes defined by Molin (2002): low yield ( $>95 \%$ ), medium yield (from 95 to $105 \%)$, and high yield (>105\%).

The pneumatic seeder at a forward speed of $5 \mathrm{~km} \mathrm{~h}^{-1}$ also presented the highest amount of area within the class above $105 \%$ (Table 7). The average percentage of yield indicated that the pneumatic mechanism presented a higher amount of area within the class above $105 \%$ when compared to the mechanical. However, the pneumatic seeder caused the largest area in the class lower than $95 \%$ and the lowest area in the medium class. Thus, a higher regularity of the mechanical seeder is suggested, as the difference in the high yield class was $3.45 \%$ between seeders, favoring the pneumatic seeder, but the difference was $14.10 \%$ for the mechanical seeder in the medium yield class, with a smaller area in the low yield class ( $9.32 \%$ difference).

TABLE 7. Percentage of harvester yield data distributed into classes.

\begin{tabular}{lccll}
\hline Seeder & $\begin{array}{c}\text { Speed } \\
\mathrm{km} \mathrm{h}^{-1}\end{array}$ & $<95 \%$ & Classes & $>105 \%$ \\
\hline Mechanical & 3 & 17.97 & 95 to $105 \%$ & 18.84 \\
& 5 & 19.68 & 63.19 & 37.74 \\
& 7 & 16.42 & 42.58 & 18.21 \\
& 9 & 17.79 & 65.37 & 26.38 \\
\hline Mean & 17.96 & 55.83 & 25.26 \\
\hline Pneumatic & 3 & 35.13 & 56.74 & 32.22 \\
& 5 & 29.57 & 32.65 & 34.03 \\
& 7 & 22.55 & 36.40 & 22.55 \\
\hline Mean & 9 & 21.89 & 49.59 & 26.20 \\
\hline
\end{tabular}


The yield map is quite visually uniform, with a predominant class between 6000 and $7000 \mathrm{~kg} \mathrm{~h}^{-1}$ (Figure 2). It can be confirmed by analyzing the coefficient of variation of the yield data obtained from the harvest monitor (lower than $30 \%$ ), also agreeing with the values shown in Table 7 and the yield map expressed as a percentage proposed by Molin (2002) (Table 7). After data interpolation, a lower yield was observed at the northern region of the experiment, which is one of the causes of soil compaction, probably caused by machinery traffic, which is

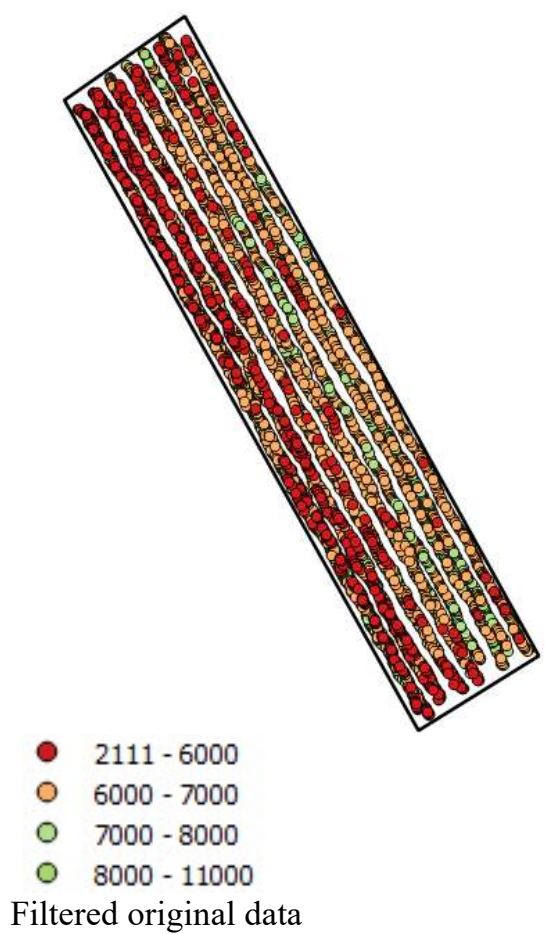

reinforced by the fact that the eastern strip is farther from the border of the field. Deperon-Júnior et al. (2016) studied the influence of tillage implements and compaction levels on physical attributes and found reductions of 15, 20, and $22 \%$ in corn grain yield when compared to 3,6 , and 9 strides of a 3.5-Mg tractor, respectively. The author also mentioned that tractor traffic increased soil resistance to penetration, reducing root expansion and the possibility of water and nutrient absorption.

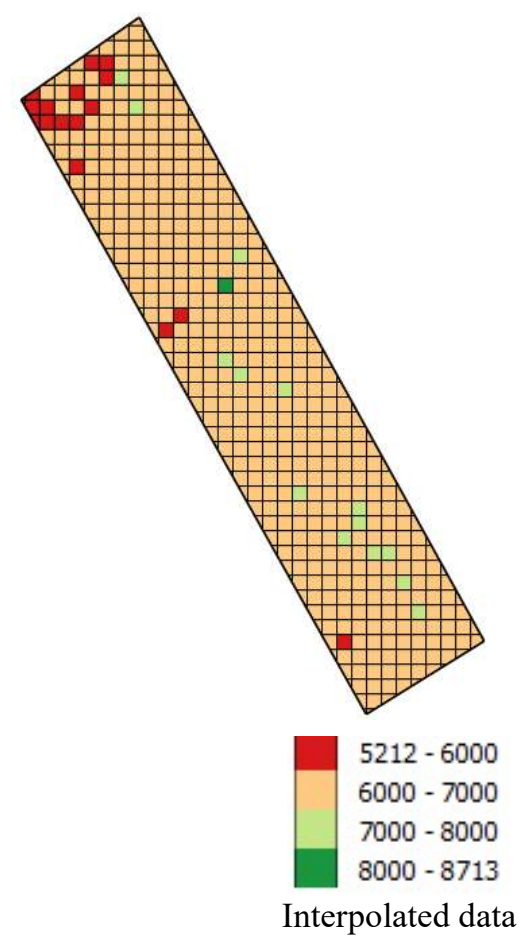

FIGURE 2. Original and interpolated yield data $\left(\mathrm{kg} \mathrm{ha}^{-1}\right)$. The original data map shows, from west to east, bands with mechanical and pneumatic seeders $\left(3,5,7\right.$, and $\left.9 \mathrm{~km} \mathrm{~h}^{-1}\right)$.

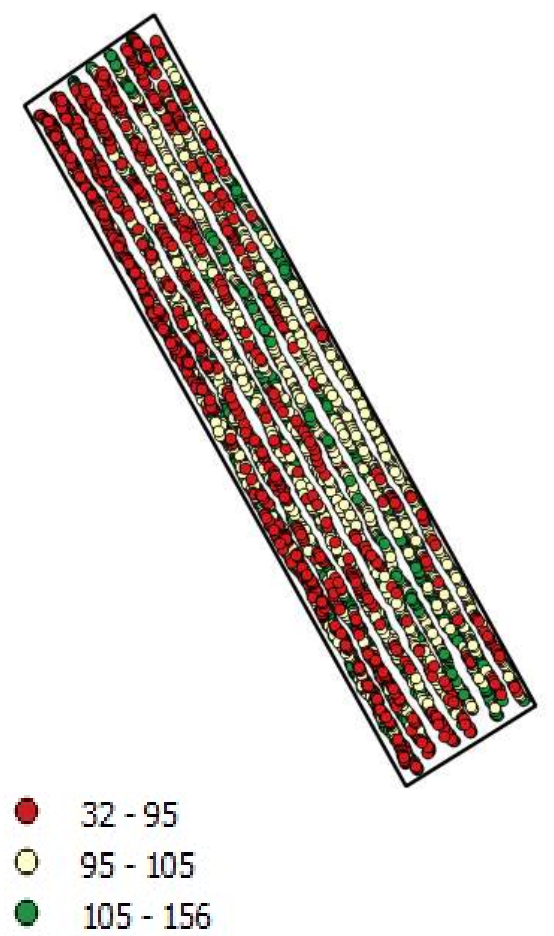

Filtered original data

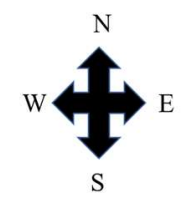

FIGURE 3. Yield data as percentages of original and interpolated data. The original data map shows, from west to east, bands with mechanical and pneumatic seeders $\left(3,5,7\right.$, and $\left.9 \mathrm{~km} \mathrm{~h}^{-1}\right)$. 


\section{CONCLUSIONS}

The pneumatic system promotes the best distribution of plants with normal spacing while increasing sowing forward speed reduces normal spacing and increases failures.

The seed metering systems and tractor-seeder forward speeds do not affect the components plant height, first ear insertion height, and stem diameter.

Yield data analyzed with precision agriculture techniques show less variation with increasing forward speed, especially in the pneumatic seeder.

When the yield data are grouped into high, medium, and low classes, it indicates better results for the mechanical seeder, especially at $5 \mathrm{~km} \mathrm{~h}^{-1}$.

\section{ACKNOWLEDGMENTS}

To CAPES for granting a master's scholarship to the second author.

\section{REFERENCES}

Alonço AS, Silveira HAT, Cardinal KM, Rist GP (2015)

Distribuição de sementes de algodão e girassol em diferentes velocidades e inclinações em dosadores pneumáticos. Scientia Agraria 16(2):63-70.

Arcoverde SNS, Souza CMA, Cortez JW, Guazina RA, Maciak PAG (2016) Qualidade do processo de semeadura da cultura do milho de segunda safra. Engenharia na agricultura 24(5):383-392.

Arcoverde SNS, Souza CMA, Cortez JW, Maciak PAG, Nagahama HJ (2017) Qualidade e variabilidade espacial na semeadura do milho de segunda safra. Energia na agricultura 32(4):386-392.

Bottega EL, Braido R, Piazetta HVL, Oliveira Neto AM, Guerra N (2014b) efeitos da profundidade e velocidade de semeadura na implantação da cultura do milho. Pesquisa Agropecuária Pernambucana 19(2):74-78.

Bottega EL, Rosolem DH, Oliveira Neto AM, Piazetta HVL, Guerra N (2014a) Qualidade da semeadura do milho em função do sistema dosador de sementes e velocidade de operação. Global scienci and technology 7(1):107-114.

Bottega EL, Vian T, Guerra N, Neto AMO (2018) Diferentes dosadores de sementes e velocidades de deslocamento na semeadura do milho em plantio direto. Pesquisa Agropecuária Pernambucana 22 (e201707):1-5.

Carpes DP, Alonço AS, Francetto TR, Moreira AR, Chagas GS (2018) Qualidade da distribuição longitudinal de sementes de milho por um dosador-apanhador com auxílio pneumático. Revista Engenharia na Agricultura 28(1):43-51.

CONAB - Companhia Nacional de Abastecimento (2019) Acompanhamento da safra brasileira, 2019. CONAB. Avaiable: https://www.conab.gov.br/infoagro/safras/graos. Accessed: Jul 22, 2019.
Cortez JW, Furlani CEA, Silva RP (2006) Semeadoras de precisão. Cultivar Máquinas 56, p.16-19.

Deperon-Júnior MA, Nagahama HJ, Olszevski N, Cortez JW, Souza E (2016) Influência de implementos de preparo e de níveis de compactação sobre atributos físicos do solo e aspectos agronômicos da cultura do milho. Engenharia Agrícola 36(2):367-376.

Dias VO, Alonço AS, Carpes DP, Veit AA, Souza LB (2014) Velocidade periférica do disco em mecanismos dosadores de sementes de milho e soja. Ciência Rural 44(11):1973-1979.

IBGE - Instituto Brasileiro de Geografia e Estatística (2018) Levantamento Sistemático da Produção Agrícola, 2018. IBGE. Available:

https://sidra.ibge.gov.br/home/lspa/brasil. Acesso em: Jan 05, 2019.

Kurachi SAH, Costa JAS, Bernardi JÁ, Coelho JLD, Silveira GM (1989) Avaliação tecnológica de semeadoras e/ou adubadoras: tratamento e dados de ensaios e regularidade de distribuição longitudinal de sementes. Bragantia 48(2):249 - 262.

Macedo DX, Nicolau FEDA, Nascimento HC, Costa E, Chioderoli CA, Loureiro DR (2016) Operational performance of a tractor-seeder according to the velocity and working depth. Revista Brasileira de Engenharia Agrícola e Ambiental 20(3):280-285.

Mialhe LG (1996) Máquinas agrícolas: ensaios \& certificação. Piracicaba, Fealq,722p.

Molin JP (2002) Definição de unidades de manejo a partir de mapas de produtividade. Engenharia Agrícola 22(1):83-92.

Nascimento FM, Rodrigues JG, Fernandes JC, Gamero CA, Bicudo SJ (2014) Efeito de sistemas de manejo do solo e velocidade de semeadura no desenvolvimento do sorgo forrageiro. Revista Ceres 61(3):332-337.

Pimentel-Gomes F, Garcia CH (2002) Estatística aplicada a experimentos agronômicos e florestais: exposição com exemplos e orientações para uso de aplicativos. Piracicaba, Fealq, 309p.

Santos VC, Santos PRA, Lima IO, Pereira VRF, Gonçalves FR, Chioderoli CA (2016) Desempenho de semeadora-adubadora em função da velocidade de deslocamento e do mecanismo sulcador de fertilizantes. Revista Brasileira de Engenharia Agrícola e Ambiental 20 (3):286-291.

Vian AL, Santi AL, Amado TJC, Cherubin MR, Simon DH, Damian JM, Bredemeier C (2016) Variabilidade espacial da produtividade de milho irrigado e sua correlação com variáveis explicativas de planta. Ciência Rural 46(3):464-471.

Weirich Neto PH, Fornari AJ, Justino A, Garcia LC (2015) Qualidade na semeadura do milho. Engenharia Agrícola 35(1):171-179. 